\author{
Jan BUREK ${ }^{1}$ \\ Joanna LISOWICZ ${ }^{2}$ \\ Tomasz RYDZAK ${ }^{3}$ \\ Artur SZAJNA ${ }^{4}$
}

\title{
PROBLEMY KSZTAŁTOWANIA UBYTKOWEGO MATERIAŁÓW KOMPOZYTOWYCH - ROZWIĄZANIA OFEROWANE PRZEZ FIRMY NARZĘDZIOWE
}

\begin{abstract}
Charakterystyczne właściwości materiałów kompozytowych, takie jak wysoka wytrzymałość i sztywność, przy jednoczesnym zmniejszeniu masy sprawiają, że zyskują coraz większe znaczenie jako materiały konstrukcyjne. Elementy kompozytowe często wymagają wykonania wykańczających operacji z zastosowaniem obróbki ubytkowej, takiej jak frezowanie lub wiercenie. Okazuje się jednak, że kształtowanie ubytkowe kompozytów - materiałów niejednorodnych i anizotropowych przysparza sporo trudności. Najczęściej napotykanym problemem jest zjawisko delaminacji, czyli rozdzielenia sąsiadujących warstw osnowy. Producenci narzędzi skrawających proponują coraz większy wybór narzędzi do obróbki kompozytów, które pozwolą na uniknięcie lub minimalizację niekorzystnych zjawisk towarzyszących obróbce materiałów kompozytowych.
\end{abstract}

Słowa kluczowe: kompozyty, problemy obróbki kompozytów, delaminacja, narzędzia do obróbki kompozytów

\section{Wprowadzenie}

Dynamiczny rozwój wielu branż związanych z budową maszyn i urządzeń, a także dążenie do zmniejszania kosztów zarówno produkcji, jak i eksploatacji skłaniają do poszukiwania nowych rozwiązań z zakresu stosowanych materiałów. Odpowiedzią na takie zapotrzebowanie jest zastosowanie materiałów kompozytowych.

Materiały te są coraz szerzej stosowane, o czym mogą świadczyć chociażby dane firm lotniczych. Airbus jako pierwszy zastosował materiały kompozytowe

\footnotetext{
${ }^{1}$ Autor do korespondencji/corresponding author: Jan Burek, Politechnika Rzeszowska, ul. Wincentego Pola 2, 35-959 Rzeszów, tel.: 178651499, e-mail: jburek@prz.edu.pl

2 Joanna Lisowicz, Politechnika Rzeszowska, e-mail: j.lisowicz@prz.edu.pl

3 Tomasz Rydzak, Politechnika Rzeszowska, e-mail: t.rydzak@ prz.edu.pl

${ }^{4}$ Artur Szajna, Politechnika Rzeszowska, e-mail: a.szajna@prz.edu.pl
} 
do budowy samolotów. Podczas produkcji samolotu Airbus A300 w latach 80 . $\mathrm{XX}$ w. kompozyty stanowiły zaledwie $5 \%$ masy całkowitej, natomiast przy produkcji samolotu Boeing 787 kompozyty stanowią już 50\% całkowitej masy samolotu $[12,13]$.

Zwiększanie udziału procentowego kompozytów w całkowitej masie maszyn i urządzeń wynika z wielu właściwości kompozytów. Kompozyty to materiały składające się z dwóch komponentów cechujących się różnymi właściwościami mechanicznymi, połączonymi na stałe z zachowaniem wyraźnej granicy rozdziału [10]. Kompozyty są więc połączeniem osnowy, której zadaniem jest nadanie kształtu strukturze oraz materiału wzmacniającego (włókien), który zapewnia odpowiednią wytrzymałość i sztywność. Tak otrzymany materiał posiada znacznie lepszy stosunek wytrzymałości do masy [5].

W kompozytach włóknistych zastosowanie znajdują osnowy: polimerowe, metalowe i ceramiczne. Z kolei jako materiał wzmacniający wykorzystuje się włókna węglowe, szklane i aramidowe oraz rzadziej ceramiczne, borowe, grafitowe i inne [6]. Kompozyty mogą się cechować różnymi właściwościami, w zależności od materiałów stanowiących osnowę oraz materiał wzmacniający. Pewne właściwości są jednak wspólne dla większości kompozytów, na przykład zmniejszenie masy oraz zwiększenie wytrzymałości i sztywności w stosunku do materiałów składowych, a także anizotropia wynikająca z orientacji włókien, która pozwala na dostosowanie projektu i procesu wytwarzania do uzyskania pożądanych właściwości wyrobu końcowego. Najczęściej są stosowane kompozyty z osnową polimerową - PMC (Polymer Matrix Composites). Wśród nich można wyróżnić $[5,7]$ :

- kompozyty wzmacniane włóknami węglowymi CFRP (Carbon Fibre Reinforced Plastics),

- kompozyty wzmacniane włóknami szklanymi GFRP (Glass Fibre Reinforced Plastics),

- kompozyty wzmacniane włóknami aramidowymi AFRP (Aramid Fibre Reinforced Plastics).

Kompozyt GFRP jest materiałem o stosunkowo dobrych właściwościach mechanicznych i niskiej cenie. Kompozyty AFRP i CFRP charakteryzują się wyższą wytrzymałością i sztywnością, przy czym wykazują mniejszą masę właściwą (gęstość). Są one jednak droższe, wobec tego znajdują zastosowanie w konstrukcjach, gdzie wyznacznikiem nie jest cena, ale prezentowane właściwości. Maksymalna temperatura pracy dla kompozytów włóknistych z osnową polimerową jest niezbyt wysoka, ponieważ polimery wykazują zdolność do zmiękczania oraz chemicznego rozkładu lub degradacji w podwyższonej temperaturze. Kompozyty $\mathrm{z}$ osnową metalową pracują $\mathrm{w}$ wyższych temperaturach niż dopuszczalne w przypadku kompozytów z osnową polimerową. Charakteryzują się największą sztywnością i wytrzymałością. Kompozyty z osnową ceramiczną charakteryzują się większą odpornością na kruche pękanie niż niewzmacniane materiały cera- 
miczne. Ponadto wykazują większy moduł sprężystości i wyższe właściwości mechaniczne w wysokich temperaturach niż odpowiednie materiały metalowe [6].

\section{Obróbka ubytkowa kompozytów}

Mimo że kompozyty ze względu na swoje właściwości stanowią bardzo atrakcyjną grupę materiałową, ich obróbka wciąż wymaga spełnienia wielu wymagań, dotyczących zarówno procesu obróbki, jak i zastosowanych narzędzi. Kształtowanie ubytkowe kompozytów stwarza znacznie więcej problemów niż obróbka materiałów metalowych. Podstawowe trudności to zła jakość powierzchni po obróbce oraz duże zużycie narzędzia. Kompozyty są wykonywane w kształcie zbliżonym do ostatecznego, z tego względu główne operacje obróbkowe, którym są poddawane materiały kompozytowe to: frezowanie, mające na celu głównie wyrównanie krawędzi elementu oraz wiercenie, wraz z pogłębianiem, służące wykonaniu otworów montażowych (pod mocowanie śrubami, nitami itp.). Ponieważ kompozyty są grupą materiałów niejednorodnych i anizotropowych, wiercenie stwarza szczególne trudności podczas obróbki, która może skutkować obniżeniem wytrzymałości, w szczególności wytrzymałości zmęczeniowej. Typowe uszkodzenia, które mogą się pojawić podczas wiercenia to delaminacja, odrywanie materiału przy wejściu/wyjściu narzędzia, pękanie międzywarstwowe, zerwanie włókien/osnowy i uszkodzenia termiczne. Ze względu na dużą odporność na ścieranie, wiercenie kompozytów powoduje duże zużycie narzędzi, co skutkuje potrzebą ich częstej wymiany, a to z kolei znacząco wpływa na cykl produkcyjny. Ponadto różne wartości współczynnika rozszerzalności cieplnej włókien i osnowy sprawiają, że utrzymanie dokładności wymiarowej wykonywanych otworów jest znacznie utrudnione [3,9].

Delaminacją, inaczej rozwarstwieniem, nazywa się proces, który w skali makroskopowej uwidacznia się jako rozdzielenie sąsiadujących warstw osnowy, co oznacza brak zdolności do przenoszenia między nimi normalnych naprężeń rozciągających oraz międzywarstwowych naprężeń ścinających. Skutkiem delaminacji jest zmniejszona nośność oraz zmniejszona integralność struktury, negatywnie wpływające na trwałość kompozytu [1,9]. Rozwarstwienie może występować zarówno na wierzchnich warstwach materiału podczas wchodzenia wiertła (rys. 1), jak i w warstwach dolnych podczas opuszczania materiału przez narzędzie. Zjawisko to występuje, gdy obciążenia pochodzące od narzędzia skrawającego przekraczają wartość wiązania międzylaminarnego [4].

Zerwanie włókien podczas wejścia narzędzia (rys. 2a) wynika z dociskania przez siłę skrawania materiału ścieranego i ciętego do powierzchni narzędzia. Początkowo ostrze wiertła ściera kompozyt. Wraz z posuwem wiertła występuje tendencja do przesuwania ścieranego materiału i „zakręcania się” zanim zostanie on skutecznie ścięty. Działanie to powoduje powstanie siły odrywania, która oddziela górne warstwy kompozytu. Siła ta jest funkcją geometrii narzędzia i tarcia pomiędzy narzędziem a przedmiotem obrabianym [2]. 


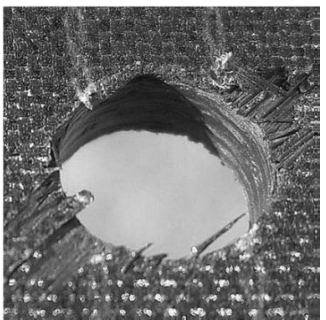

Rys. 1. Rozwarstwienie i uszkodzenia wierzchniej warstwy CFRP mogące wystąpić podczas wiercenia otworu

Fig. 1. Delamination and damage of the top layer of CFRP occurring during hole drilling

Gdy wiertło zbliża się do ostatnich warstw materiału, grubość pozostałych warstw pod narzędziem maleje, co prowadzi do osłabiania sztywności warstw nieobrobionych. Skutkuje to odkształceniem spodnich warstw pod wpływem zginania, a w rezultacie do rozprzestrzeniania się pęknięć w osnowie, czego wynikiem jest delaminacja (rys. 2b). Delaminacja pojawiająca się podczas wychodzenia narzędzia to najczęściej spotykany defekt podczas obróbki kompozytów [8]. Zużycie narzędzia jest wynikiem odporności na ścieranie kompozytów i ich małej przewodności cieplnej. Powoduje to znaczne nagrzewanie narzędzia. Podczas wiercenia CFRP 50\% energii jest pochłaniane przez narzędzie, natomiast w przypadku wiercenia metali tylko $18 \%$ energii pochłania wiertło [2].

a) Obrabiany materiał "zakręca się" wokół wiertla

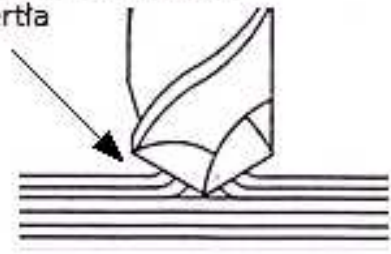

b)

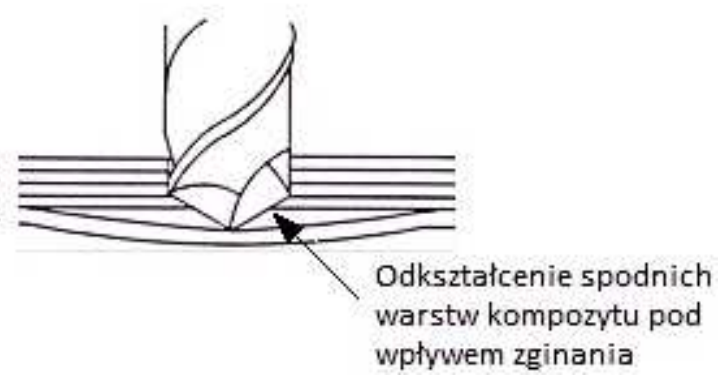

Rys. 2. Zjawisko delaminacji: a) podczas wchodzenia narzędzia w materiał, b) podczas wychodzenia narzędzia z materiału

Fig. 2. Delamination phenomenon: a) peel-up delamination at entrance, b) push-out delamination at exit

Kompozyty są zazwyczaj wykonywane w kształcie zbliżonym do ostatecznego, wobec tego frezowanie ma na celu tylko wyrównanie krawędzi. Jest to zatem obróbka wykańczająca z małymi naddatkami obróbkowymi. Podczas frezowania często zdarza się, że w tym samym momencie kilka krawędzi skrawających bierze udział w obróbce. Należy także uwzględnić fakt, że orientacja włókien, rozmiar wiórów i siły skrawania zmieniają swoje wartości wraz z obrotem narzędzia. Podstawowe problemy pojawiające się podczas frezowania kompozy- 
tów to: zużycie narzędzia, delaminacja i chropowatość powierzchni. Zużycie narzędzia podczas frezowania wynika głównie z udarowego charakteru pracy i wysokiej odporności kompozytu na ścieranie. Ponadto znaczna część ciepła wytwarzanego podczas obróbki jest odprowadzana przez narzędzie.

Delaminacja materiału podczas frezowania wynika głównie z działania siły osiowej, która jest skierowana w kierunku normalnym do płaszczyzny kompozytu, wobec czego jej działanie może powodować odrywanie poszczególnych warstw (rys. 3). Efekt ten jest najbardziej widoczny na górnych i dolnych powierzchniach obrabianej krawędzi materiału [15].

Rys. 3. Zniszczenie materiału na górnej powierzchni elementu podczas procesu frezowania

Fig. 3. Workpiece damage on the top surface of element during milling process

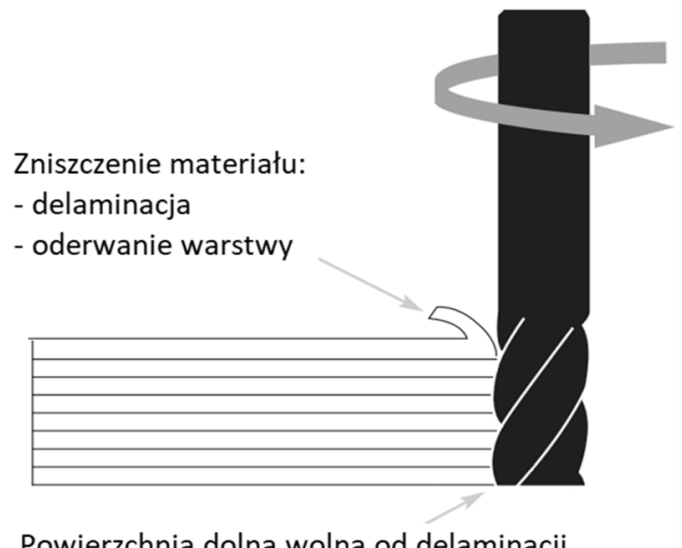

Obróbkę skrawaniem włóknistych polimerowych materiałów kompozytowych prowadzi się specjalnie skonstruowanymi narzędziami. W zależności od sposobu wykorzystania i przeznaczenia narzędzi (np. obróbka zgrubna lub wykańczająca) materiały, z których są wykonane, mogą się znacznie różnić. Podstawowym materiałem narzędziowym są węgliki spiekane, najczęściej z nałożonymi odpowiednimi powłokami. Do powłok stosowanych na narzędzia przeznaczone do obróbki kompozytów zalicza się:

- powłokę diamentową nanoszoną metodą CVD,

- powłokę diamentopodobną (DLC),

- powłokę filmu diamentowego (DFC),

- powłokę z azotku cyrkonu (ZNC),

- powłokę z krystalicznego diamentu (CDC).

Powłoki diamentowe są stosowane do obróbki kompozytów ze względu na korzystne właściwości: dobre przewodnictwo cieplne, chemiczną bierność w stosunku do żywic w wysokich temperaturach, mały współczynnik tarcia. Powłoki diamentowe zapewniają także narzędziom nawet 10-krotnie wyższą trwałość. 
Geometria narzędzi jest jeszcze bardziej zróżnicowana niż wybór powłok. Ze względu na specyficzne właściwości kompozytów narzędzia muszą posiadać odpowiednią geometrię. Liczba i kształt rowków wiórowych oraz kąt pochylenia linii śrubowej wpływają na zdolność odprowadzania wiórów ze strefy obróbki, a zatem także na temperaturę w strefie obróbki i jakość powierzchni. Kąt wierzchołkowy i sposób ukształtowania powierzchni natarcia wpływają natomiast na prawdopodobieństwo wystąpienia zjawiska delaminacji. W przypadku frezowania produkowane są frezy z przeciwstawnymi ostrzami, tzw. frezy kompresyjne, które mają przeciwbieżne rowki wiórowe i na zasadzie nożyc ,ściskają” kompozyt od góry i od dołu, zapobiegając w ten sposób zjawisku rozwarstwiania (rys. 4). Podczas wiercenia materiałów kompozytowych ogromne znaczenie ma kąt wierzchołkowy narzędzia. Ponadto wiertła do obróbki materiałów PMC są często wykonywane ze zmiennymi średnicami w sposób ciągły lub stopniowy (rys. 5). Zasada działania takich wierteł polega na rozpoczęciu wykonywania otworu od małej średnicy, stopniowo zwiększając jej wielkość, aż do osiągnięcia założonej wartości [7].

a)

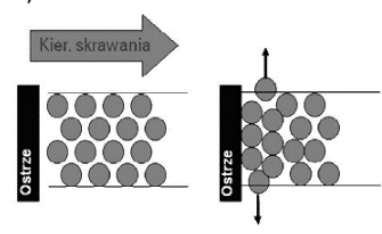

b)

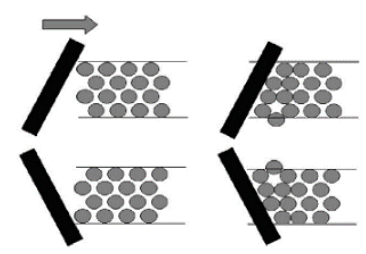

Rys. 4. Frezowanie kompozytów: a) frezem klasycznym, b) frezem kompresyjnym

Fig. 4. Composites milling using: a) standard end mill, b) compression-style router

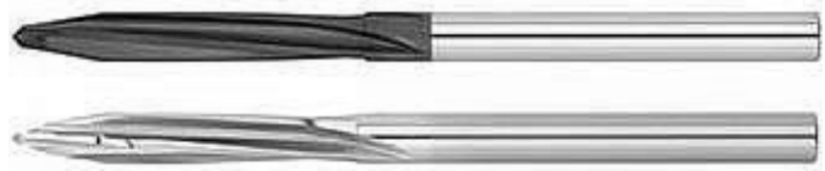

Rys. 5. Wiertła firmy Amanco charakteryzujące się w części czołowej ciągłym wzrostem średnicy narzędzia, aż do osiągnięcia wymaganej średnicy otworu

Fig. 5. Amanco drills characterized by a continuous tool diameter increase in the front face until obtaining the required hole diameter

Wybór parametrów obróbki, takich jak: prędkość obrotowa, prędkość posuwu oraz głębokość skrawania, ma wpływ na siły skrawania pojawiające się podczas obróbki, czyli także na jakość powierzchni, wielkość delaminacji i prędkość 
zużycia narzędzia. Rysunek 6 przedstawia wykres siły skrawania w funkcji wartości prędkości obrotowej i prędkości posuwu narzędzia podczas frezowania krawędzi panelu wykonanego z CFRP czteropiórowym frezem spiralnym do obróbki wykańczającej. Jak wynika z wykresu, wraz ze wzrostem prędkości obrotowej obie składowe siły skrawania maleją, natomiast wraz ze wzrostem prędkości posuwu obie składowe rosną.

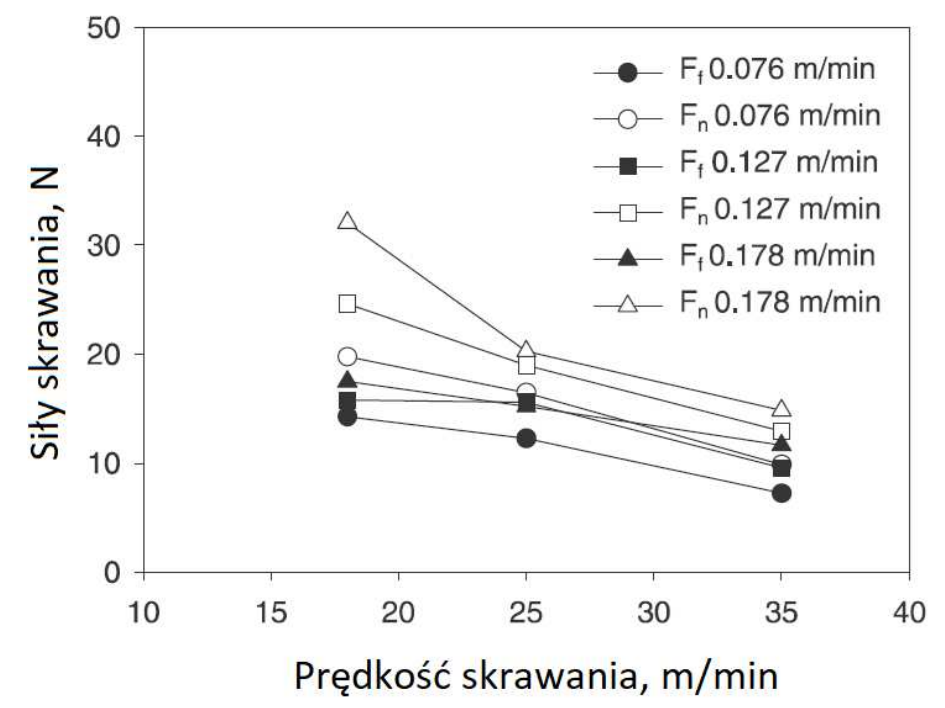

Rys. 6. Zależność siły normalnej $F_{n}$ i siły stycznej $F_{t}$ w funkcji prędkości obrotowej i prędkości posuwu podczas frezowania kompozytu CFRP

Fig. 6. Variation of normal force $F_{n}$, and tangential force $F_{t}$, as a function of a cutting speed and feed rate in milling of CFRP composite

\section{Rozwiązania stosowane przez firmy narzędziowe}

W związku z coraz szerszym zastosowaniem kompozytów przedsiębiorstwa zajmujące się produkcją narzędzi poszukują coraz to nowych rozwiązań likwidujących lub co najmniej zmniejszających skalę problemów związanych z ich obróbką. Firma Kennametal do wiercenia otworów w kompozytach proponuje wykorzystanie wierteł pełnowęglikowych $\mathrm{z}$ wielowarstwową powłoką diamentową, zapewniającą znacznie dłuższą trwałość narzędzia (rys. 7). Geometria została zaprojektowana tak, aby kąt wierzchołkowy $90^{\circ}$ zwiększał możliwość centrowania narzędzia, jednocześnie zmniejszając nacisk. Wynikiem tego jest znacznie lepsza jakość powierzchni otworu. Ponadto firma Kennametal proponuje obróbkę otworów narzędziami do orbitalnego wiercenia (rys. 8). Narzędzia są pokryte powłoką diamentową KCN05. 
$90^{\circ}$

$90^{\circ}$

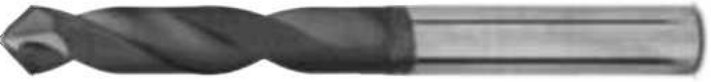

$90^{\circ}$

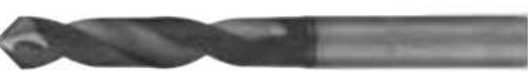

Rys. 7. Wiertła do obróbki CFRP firmy Kennametal

Fig. 7. Kennametal drills for CFRP machining

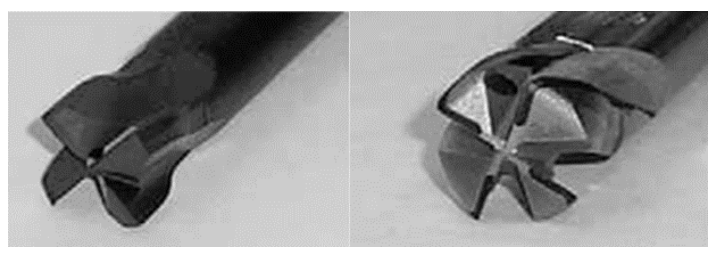

Rys. 8. Narzędzia firmy Kennametal do wiercenia orbitalnego materiałów CFRP

Fig. 8. Kennametal tools for CFRP orbital drilling

W przypadku frezowania firma Kennametal proponuje wykorzystanie czterech rodzajów frezów [14]:

- Compression-Style Router (rys. 9a) - o kącie nachylenia linii śrubowej 25, zaprojektowanych do obróbki z dużymi prędkościami posuwu, pozostawiających doskonałą jakość powierzchni po obu stronach materiału,

- Burr-Style Routers (rys. 9b) - o kącie nachylenia linii śrubowej $15^{\circ}$, pozwalających na doskonałą kontrolę temperatury, jednocześnie pozostawiających powierzchnię dobrej jakości,

- Down-Cut-Style Router (rys. 9c) - o kącie nachylenia linii śrubowej $25^{\circ}$, idealnie nadających się do obróbki kieszeni, o geometrii zaprojektowanej tak, aby eliminować zjawisko delaminacji,

- Ball-End-Style Routers (rys. 9d) - o kącie nachylenia linii śrubowej 30, przystosowanych do obróbki rowków i profili przy jednoczesnym małym zużyciu narzędzia.

a)

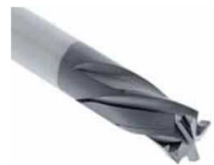

c)

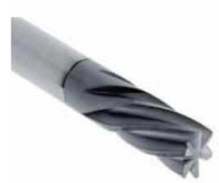

b)

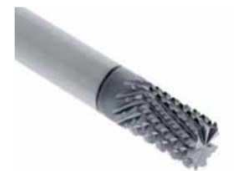

d)

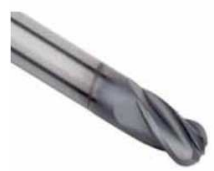

Rys. 9. Frezy do obróbki kompozytów CFRP: a) Compression-Style Router, b) Burr-Style Router, c) Down-Cut-Style Router, d) Ball-EndStyle Router

Fig. 9. Milling cutters for CFRP machining: a) Compression-Style Router, b) Burr-Style Router, c) Down-Cut-Style Router, d) Ball-EndStyle Router 
Firma Sandvik jako rozwiązanie do obróbki otworów w kompozytach proponuje wiertło CoroDrill Delta-C R854 (rys. 10). Jest ono pokryte odporną na ścieranie powłoką diamentową N30C, która ma zapewnić redukcję przestojów, dzięki dłuższemu cyklowi pracy. Ponadto drobnoziarnista struktura wiertła zapewnia większe bezpieczeństwo obróbki, natomiast geometria (mały kąt wierzchołkowy i duży kąt natarcia) narzędzia gwarantuje lepszą jakość i dokładność wykonania otworów oraz zmniejsza prawdopodobieństwo zginania cienkich elementów dzięki zmniejszeniu siły nacisku oraz wartości momentu obrotowego.

Rys. 10. Wiertło CoroDrill Delta-C R854 firmy Sandvik do obróbki kompozytów

Fig. 10. Sandvik drill CoroDrill Delta-C R854 for composite materials machining

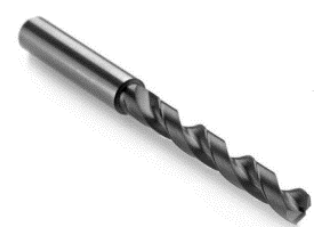

W przypadku frezowania materiałów kompozytowych wzmocnionych włóknem węglowym (CFRP) firma Sandvik proponuje zastosowanie następujących frezów trzpieniowych:

- CoroMill Plura z przeciwstawnymi ostrzami (rys. 11a) - frezy trzpieniowe z dwoma liniami śrubowymi najlepiej sprawdzają się w warstwach z włókien szklanych po obu stronach obrabianego przedmiotu; dwa nakładające się przeciwstawne rowki umożliwiają obróbkę cieńszych materiałów ograniczając ich drgania; zoptymalizowany kształt rowka wiórowego najlepiej sprawdza się podczas obróbki płaskich przedmiotów, podczas której nie można poruszać narzędziem na boki,

- CoroMill Plura z małym kątem pochylenia linii śrubowej (rys. 11b) - pozwala na uzyskanie gładkiej powierzchni podczas obróbki wykończeniowej; zaprojektowany do pracy z dużymi prędkościami,

- CoroMill Plura ząbkowany (rys. 11c) - zapewnia wysoką wydajność skrawania; geometria zapewniająca lepszy podział wióra pozwala ograniczyć rozwarstwienia i drgania; geometrię zoptymalizowano pod kątem obróbki w jednym przejściu.

a)

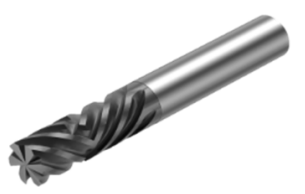

b)

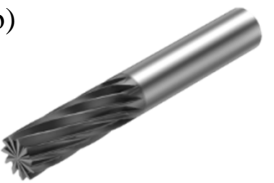

c)

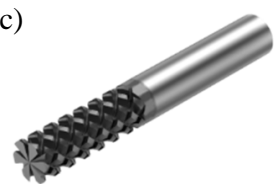

Rys. 11. Narzędzia do frezowania kompozytów firmy Sandvik: a) CoroMill Plura z przeciwstawnymi ostrzami, b) CoroMill Plura z małym kątem pochylenia linii śrubowej, c) CoroMill Plura ząbkowany

Fig. 11. Sandvik tools for composite milling: a) CoroMill Plura compression router, b) CoroMill Plura low helix routers, c) CoroMill Plura serrated routers 
Ponadto firma Sandvik do obróbki kompozytów proponuje narzędzia składane, np. CoroMill 590 - do frezowania powierzchni z CFRP (rys.12a), z wymiennymi płytkami z pokryciem PCD i bardzo precyzyjnym osadzeniem w gnieździe, zapewniającym dużą dokładność, CoroMill 390 (rys. 12b) - do powierzchni rzeźbionych metodą Sturtza (do profilowania włókna węglowego narzędziem nachylonym pod kątem $2-10^{\circ}$, poruszającego się z dużym posuwem - rozwiązanie to nadaje się do detali 2D i 3D, jest wykorzystywane do frezowania podzespołów skrzydeł i kadłubów samolotów) [17].

a)

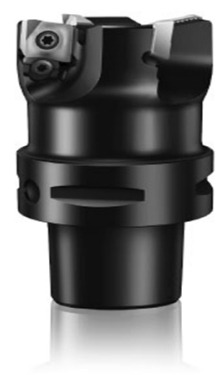

b)

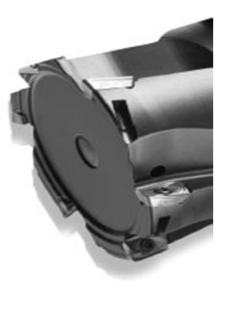

Rys. 12. Wiertła do obróbki kompozytów firmy Sandvik: a) CoroMill 590, b) CoroMill 390

Fig. 12. Sandvik drills for composites machining: a) CoroMill 590, b) CoroMill 390

Rozwiązania oferowane przez firmę Onsrud są następujące:

- Solid Carbide 8-Facet Drill (rys. 13a) - dwa kąty wierzchołkowe: 90 i $118^{\circ} \mathrm{z}$ dwiema powierzchniami natarcia przy każdym kącie tworzą geometrię, której zadaniem jest eliminacja zjawiska delaminacji,

- PCD 8-Facet Point Drill (rys. 13b) - geometria została zaprojektowana w taki sposób, aby zwiększyć dokładność wykonania otworu, dzięki wykorzystaniu drugiego kąta wierzchołkowego, który zapewnia działanie rozwiercające, przeciwstawiające się naciskom bocznym. Geometria ta umożliwia także dobre łamanie wiórów, ponieważ pierwsza i druga krawędź skrawająca zapewniają tworzenie kątowej wstęgi, która łamie się łatwiej i zapobiega uszkodzeniu ścianki otworu wykonanego w materiale CFRP,

- Nano-Crystaline Thin Film Diamond Drill (rys. 13c) - tańsza alternatywa dla wiertła PCD. Paraboliczny kształt rowków został zaprojektowany tak, aby umożliwić pomieszczenie większej objętości wiórów,

- Solid Carbide Carbon Graphite Cutter (rys. 13d) - większa liczba krawędzi skrawających oraz łamacz wiórów i krawędzie wykańczające zapewniające redukcję sił skrawania pozwalają na prowadzenie narzędzia $\mathrm{z}$ większymi wartościami prędkości posuwowych. Liczne rowki wiórowe pozwalają na lepszy przepływ i ewakuację wiórów [16].

Rozwiązania proponowane przez firmę Gühring to przede wszystkim frezy do frezowania kompresyjnego:

- monolityczne frezy węglikowe o lewo-prawoskrętnych ostrzach skrawających (rys. 14a), 
- frezy kompresyjne o dużym skręcie ostrzy, opracowane dla materiałów cienkich i typu plaster miodu (rys. 14b),

- frezy kompresyjne z ostrzami PKD (jedno ostrze lewo-, drugie prawoskrętne) (rys. 14c).

Firma Gühring opracowała także narzędzia z wewnętrznym chłodzeniem, z wylotem skierowanym wstecz oraz przykrycie strefy skrawania dodatkową przestrzenią z wyciągiem pyłów (rys. 15). Rozwiązanie takie wydłuża trwałość narzędzia oraz umożliwia prowadzenie czystego, bezpiecznego procesu obróbki [11].

Rys. 13. Narzędzia do obróbki kompozytów produkowane przez firmę Onsrud: a) Solid Carbide 8-Facet Drill, b) PCD 8-Facet Point Drill, c) Nano-Crystaline Thin Film Diamond Drill, d) Solid Carbide Carbon Graphite Cutter

Fig. 13. Tools for composite materials machining produced by Onsrud company: a) Solid Carbide 8-Facet Drill, b) PCD 8-Facet Point Drill, c) NanoCrystaline Thin Film Diamond Drill, d) Solid Carbide Carbon Graphite Cutter

a)

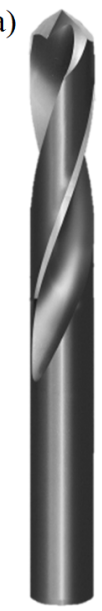

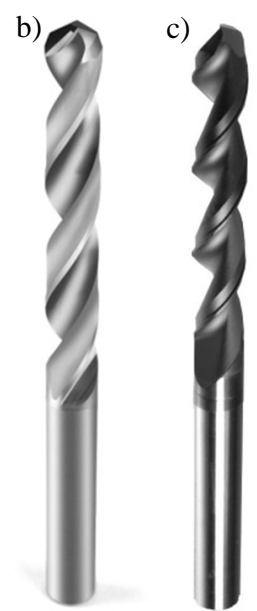

d)

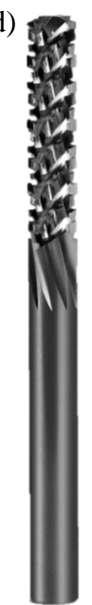

a)

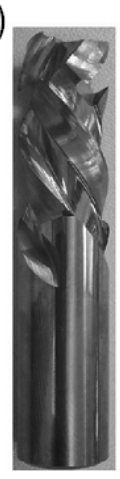

b)

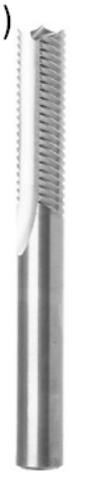

c)

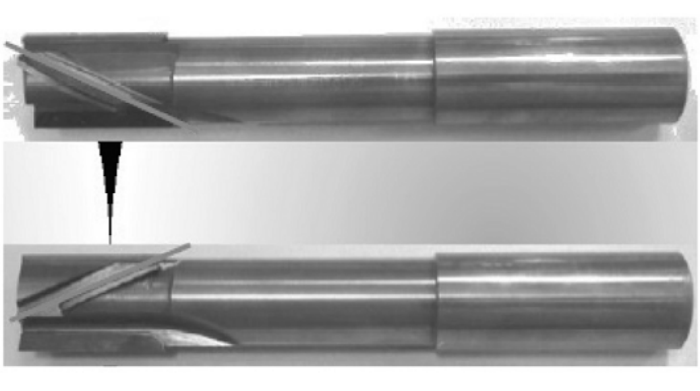

Rys. 14. Przykłady frezów firmy Gühring do frezowania kompresyjnego: a) frez węglikowy o lewo-prawoskrętnych ostrzach skrawających, b) frez kompresyjny o dużym skręcie ostrzy opracowany dla materiałów cienkich i typu plaster miodu, c) frez kompresyjny z ostrzami PKD

Fig. 14. Examples of Gühring compression-style routers: a) carbide cutter with left-right cutting blades, b) compression cutter with high blade twist developed to cut thin and honeycomb materials, c) compression cutter with PKD blades 


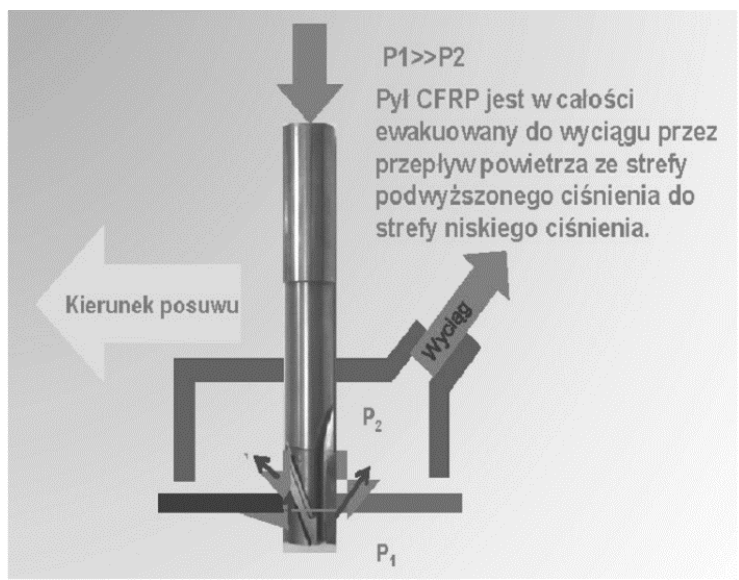

Rys. 15. Wsteczne odprowadzenie chłodziwa

Fig. 15. Reverse coolant evacuation

\section{Podsumowanie}

Coraz szersze stosowanie kompozytów w różnych gałęziach przemysłu oraz ich specyficzne właściwości wymuszają poszukiwanie coraz to nowych rozwiązań konstrukcyjnych narzędzi, które umożliwią prawidłową obróbkę detalu i pozwolą na uzyskanie dobrej jakościowo powierzchni, pozbawionej na przykład zjawiska delaminacji. Rozwiązania oferowane przez poszczególne firmy wydają się być podobne, jednak często nawet niewielka zmiana konstrukcyjna (np. zmiana o kilka stopni kąta nachylenia linii śrubowej lub wprowadzenie przeciwstawnych ostrzy) może znacząco wpłynąć na efekt końcowy obróbki. Ponadto dużą rolę odgrywa stosowanie odpowiedniego rodzaju powłok, które mogą znacznie wydłużyć czas pracy narzędzia. Oprócz badań rozwiązań konstrukcyjnych powinny być również prowadzone badania w kierunku optymalnego doboru parametrów obróbki względem danego rodzaju kompozytu. Optymalizacja ta pozwoliłaby na łatwiejszy dobór narzędzi, jak również skrócenie czasu i zmniejszenie kosztów produkcji oraz uzyskanie żądanej jakości powierzchni.

\section{Literatura}

[1] Czarnocki P.: Metodyka wyznaczania odporności na rozwarstwienia laminatów polimerowych, [w:] Polimery i kompozyty konstrukcyjne, ed. G. Wróbel, Warszawa 2010, ss. 77-99.

[2] Durão L.M.P.: Machining of hybrid composites, PhD. Thesis, Porto 2005, pp. 37-39.

[3] Leppert T., Paczkowski T., Polasik R., Serwacki D.: Delaminacja materiału kompozytowego włóknistego podczas wykonywania otworów, Mechanik, 89 (2016) $1422-1423$.

[4] Mohan N.S., Kulkarni S.M., Ramachandra A.: Delamination analysis in drilling process of glass fiber reinforced plastic (GFRP) composite materials, J. Mat. Proc. Technol., 186 (2007) 265-271. 
[5] Mrazova M.: Advanced composite materials of the future in aerospace industry, INCAS Bulletin, 5 (2013) 138-150.

[6] Oczoś K.: Kompozyty włókniste - właściwości, zastosowanie, obróbka ubytkowa, Mechanik, 81 (2008) 579-592.

[7] Oczoś K.: Problemy kształtowania ubytkowego kompozytów włóknistych z osnową polimerową i ceramiczną, Mechanik, 84 (2011) 5-10.

[8] Rahmé P., Landon Y., Lachaud F., Piquet R., Lagarrigue P.: Analytical models of composite material drilling, Int. J. Adv. Manuf. Technol., 52 (2011) 609-617.

[9] Sheikh-Ahmad J.: Machining of Polymer Composites, Springer, 2009, pp. 160-210.

[10] Stadnicki J., Marszałek J.: Doświadczalne badanie delaminacji kompozytu warstwowego według I i II schematu pękania, Mechanik, 89 (2016) 818-819.

[11] Subbotko R.: Obróbka materiałów dla przemysłu lotniczego, Mechanik, 86 (2013) 670-672.

[12] http://www.airbus.com/innovation/proven-concepts/in-manufacturing/ (dostęp: 25.05.2017 r.).

[13] http://www.boeing.com/commercial/aeromagazine/articles/qtr_4_06/article_04_2. html (dostęp: 25.05.2017 r.).

[14] https://www.kennametal.com/content/dam/kennametal/kennametal/common/Res ources/Catalogs-Literature/Industry\%20Solutions/Composite_material_machining _guide_Aerospace.pdf (dostęp: 25.05.2017 r.).

[15] https://www.kennametal.com/en/prozducts/20478624/556249/3924453/7824532/ 100001314.html (dostęp: 25.05.2017 r.).

[16] http://www.mmsonline.com/articles/tool-selection-for-composites (dostęp: 25.05. 2017 r.).

[17] http://www.sandvik.coromant.com/pl-pl/products/composite-solutions/pages/edgemilling.aspx (dostęp: 25.05.2017 r.).

\section{PROBLEMS OF MACHINING OF COMPOSITE MATERIALS - SOLUTIONS OFFERED BY TOOL COMPANIES}

\section{S u m m a r y}

The characteristic properties of composite materials, such as high strength and stiffness while reducing weight, make them increasingly important as construction materials. Composite components often require finishing operations, such as milling and drilling. However, the loss shaping of composites - nonhomogeneous and anisotropic materials - turns out to be problematic and difficult. The most common problem is the phenomenon of delamination - the separation of adjacent warp plies. Cutting tool manufacturers offer an increasing choice of composite processing tools to avoid or minimize the disadvantageous effects associated with composite materials processing.

Keywords: composites, problems with composites machining, delamination, tools for composites machining

DOI: $10.7862 / \mathrm{rm} .2017 .40$

Przestano do redakcji: 11.08 .2017

Przyjęto do druku: 10.10 .2017 
